\title{
Pengaruh ROE, EPS, OCF, Size, DER, CR dan Growth Terhadap Kebijakan Dividen pada Perusahaan Manufaktur di Bursa Efek Indonesia (BEI)
}

\author{
Crystha Armereo $^{1}$ dan Pipit Fitri Rahayu ${ }^{2}$ \\ 1-2 Jurusan Akuntansi, Universitas Tridinanti Palembang \\ Email: crystha_armereo@univ-tridinanti.ac.id \\ Email: pipitfitrirahayu@univ-tridinanti.ac.id
}

\begin{abstract}
The objective of this research is to identify the influence of return on equity, earnings per share, operating cash flow, size, debt to equity ratio, current ratio, and growth to dividend payout. Data collected from manufacturing companies that listed on Indonesian Stock Exchange for three years period 2014 to 2016. Sample selected by using purposive sampling method. There are 38 companies meet the criteria and used as sample. The statistical method used in this research is multiple regression. Result of this research showed that return on equity, earnings per share, and growth have influence dividend payout but operating cash flow, size, debt to equity ratio, and current ratio have no influence towards dividend policy.
\end{abstract}

Keywords: Dividend Policy, Return on Equity, Earnings per Share, Current Ratio, Operating Cash Flow Size

\begin{abstract}
Abstrak
Tujuan penelitian ini adalah untuk mengidentifikasi pengaruh return on equity, earnings per share, return on equity, operating cash flow, size, debt to equity ratio, current ratio, dan growth terhadap kebijakan dividen. Data dikumpulkan dari perusahaan manufaktur di Bursa Efek Indonesia selama tiga tahun periode dari tahun 2014 hingga 2016. Sampel diseleksi menggunakan metode purposive sampling method. Hanya 38 perusahaan yang sesuai dengan kriteria dan digunakan sebagai sampel. Penelitian ini diuji dengan menggunakan metode statistik multiple regression. Hasil penelitian ini menunjukkan bahwa return on equity, earnings per share, dan growth memiliki pengaruh terhadap kebijakan dividen tetapi operating cash flow, size, debt to equity ratio, dan current ratio tidak memiliki pengaruh terhadap kebijakan dividen.
\end{abstract}

Kata kunci: Kebijakan Dividen, Return on Equity, Earnings per Share, Current Ratio, Operating Cash Flow Size

\section{Pendahuluan}

Kebijakan dividen adalah kebijakan yang dibuat oleh perusahaan untuk menentukan seberapa besar pendapatan yang akan dibagikan sebagai dividen atau akan dijadikan laba ditahan (retained earnings) perusahaan untuk selanjutnya diinvestasikan kembali kepada proyek - proyek yang lebih menguntungkan dan akan berdampak pada peningkatan pertumbuhan dan nilai perusahaan (Deitiana 2009, 57). Bagi para investor kebijakan dividen yang stabil dan dividend payout ratio yang tinggi memiliki daya tarik tersendiri, karena dividen yang stabil merupakan indikasi kesehatan perusahaan dan prospek yang baik bagi perusahaan. Dasar masalah inilah yang akhirnya memikat peneliti untuk memilih topik ini untuk dijadikan bahan penelitian dan mengembangkannya di negara berkembang seperti di Indonesia dan tentunya menggunakan variabel yang berkaitan dengan pembayaran dividen, sehingga faktor - faktor yang mempengaruhi kebijakan dividen dapat diketahui. 
Peneliti juga memfokuskan penelitian pada perusahaan manufaktur yang terdaftar di BEI (Bursa Efek Indonesia) untuk tahun 2014 sampai dengan tahun 2016 yang mempunyai nilai kapitalisasi pasar yang besar dan termasuk saham yang banyak diminati dan liquid serta akan disesuaikan setiap satu tahun, dengan demikian perusahaan yang akan diteliti selalu bisa berubah oleh sebab itu peneliti akan memberlakukan kriteria - kriteria tertentu untuk memperjelas penelitian. Sehubungan dengan pentingnya peranan kebijakan dividen dalam suatu perusahaan, adanya hasil yang tidak konsisten dari penelitian sebelumnya dan untuk mengetahui faktor - faktor apa saja yang berpengaruh terhadap kebijakan dividen sehingga timbul motivasi dan ketertarikan untuk menguji kembali penelitian - penelitian sebelumnya untuk mendapatkan bukti empiris. Penelitian ini dilakukan untuk mengembangkan penelitian sebelumnya yang dilakukan oleh Adil et al. (2011) dengan tujuan untuk mengetahui variabel - variabel independen apa saja yang mempengaruhi kebijakan dividen.

Penelitian ini mereplikasi Adil et al. (2011) dengan beberapa perbedaan dengan penelitian sebelumnya karena peneliti ingin mencoba meneliti dengan faktor - faktor yang diteliti oleh Adil et al. (2011), faktor - faktor tersebut adalah Return On Equity (ROE), Earnings Per Share (EPS), Operating Cash Flow (OCF), Size (S). Maka dari itu, peneliti menambahkan variabel - variabel lain yang didapatkan dari sumber penelitian lain seperti penelitian Deitiana (2009), yaitu variabel Debt to Equity Ratio (DER) dan Current Ratio (CR), variabel ini ditambahkan karena financial leverage (DER) menunjukkan kemampuan perusahaan memenuhi seluruh hutangnya dengan modal sendiri sehingga ketika ada peningkatan hutang akan mempengaruhi tingkat pendapatan bersih yang tersedia bagi pemegang saham dan akan menurunkan kemampuan perusahaan dalam membayar dividen (Deitiana 2009).

Sedangkan variabel likuiditas (CR) ditambahkan karena likuiditas mencerminkan kemampuan perusahaan dalam memenuhi kebutuhan operasionalnya terutama modal kerja yang sangat penting untuk menjaga kinerja perusahaan, ketika kinerja perusahaan baik maka banyak investor yang ingin memiliki saham perusahaan tersebut sehingga perusahaan dapat meningkatkan harga sahamnya dan meningkatkan pembayaran dividennya (Deitiana 2013). Kemudian variabel growth direplikasi dari penelitian Marietta dan Sampurno (2013). Variabel ini ditambahkan karena tingkat pertumbuhan yang tinggi menandakan adanya kesempatan investasi yang tinggi serta membutuhkan dana dari investor (Holder et al. 1998 dalam Marietta dan Sampurno 2013) sehingga jika perusahaan harus membayarkan dividen, maka perusahaan harus mencari dana dari pihak eksternal. Alasan pemilihan variabel-variabel tersebut adalah dalam penelitian-penelitian sebelumnya, variabel-variabel tersebut telah diuji tetapi dalam kurun waktu yang berbeda-beda dan diuji dengan variabel-variabel yang berbeda-beda pula dan walaupun telah diuji dengan variabel yang sama namun memiliki hasil yang bervariasi.

\section{Landasan Teori dan Teori Kebijakan Dividen}

Berikut ini adalah teori - teori yang bermunculan seiring dengan penelitian yang terkait dengan dividen :

a. Dividend Relevance Theory (Gordon's Model)

Menurut Gordon, kebijakan dividen mempunyai pengaruh terhadap nilai perusahaan. Menurut teori ini, investor akan lebih menyukai pembayaran dividend yang akan diterima saat ini karena merasa lebih aman dari pada capital gains yang akan diterima pada masa mendatang yang penuh dengan risiko dan ketidak - pastian 
(Kurniawan 2013). Teori ini juga biasa dikenal dengan nama The Bird in The Hand Theory.

b. Dividend Irrelevance Theory

Teori ini menyatakan bahwa kebijakan dividen tidak mempunyai pengaruh terhadap nilai perusahaan maupun biaya modalnya. Teori ini dikemukakan oleh Modigliani dan Miller (M-M) yang mengatakan bahwa nilai suatu perusahaan tidak ditentukan oleh besar kecilnya Dividend Payout Ratio (DPR) tetapi melainkan ditentukan oleh laba bersih sebelum pajak (EBIT) dan risiko bisnis yang ada.

c. Tax Preference Theory

Menurut teori ini, investor akan memilih apakah akan menerima distribusi pendapatan perusahaan sebagai dividend atau capital gains. Suwaldiman dan Aziz (2006) mengungkapkan bahwa ada tiga alasan yang berkaitan dengan pajak dengan beranggapan bahwa investor lebih tertarik dengan pembagian dividen yang rendah dari pada yang tinggi.

d. Dividend Signaling Theory

Dividend signaling theory digunakan untuk membuktikan bahwa pengumuman pembayaran dividen mengandung informasi baik atau positif. Ross (1977) dalam Embara et al. (2012) mengemukakan bahwa manajer sebagai orang dalam (internal) yang mempunyai informasi yang lengkap tentang arus kas perusahaan, akan memilih untuk menciptakan isyarat yang jelas mengenai masa depan perusahaan apabila mereka mempunyai alasan atau motivasi yang tepat untuk melakukannya.

e. The Residual Theory of Dividend Payments

Teori residu dividen ini menyatakan bahwa para investor lebih senang jika perusahaan menahan labanya untuk diinvestasikan kembali kepada proyek - proyek yang lebih menguntungkan dibandingkan untuk membagi dividennya. Menurut Sundjaja dan Barlian (2003, 383-387) dalam Kurniawan (2013) hal ini dikarenakan reinvestasi akan menghasilkan return yang lebih besar dengan risiko yang sebanding. Teori ini menjelaskan bahwa dividen yang dibayarkan oleh perusahaan emiten merupakan sisa (residu) setelah dilakukan pembayaran atas kesempatan peluang investasi yang dilakukan.

Penelitian ini bertujuan untuk menguji teori yang pertama, yaitu dividend relevance theory, karena hampir sesuai dengan kondisi yang ada di Indonesia saat ini, investor akan menyukai dividen yang tinggi dibandingkan dengan capital gains yang penuh dengan ketidak - pastian. Menurut teori ini, dividen akan berpengaruh terhadap nilai perusahaan maupun biaya modalnya. Proksi yang digunakan adalah Return on Equity, Earnings per Share, Operating Cash Flow, Firm's Size, Current Ratio, Debt to equity Ratio, Firm's Growth, dan Dividen Payout Ratio pada periode 2014 - 2016. Kedelapan proksi tersebut akan mencerminkan nilai perusahaan.

\section{Kebijakan Dividen}

Kebijakan Deviden adalah kebijakan untuk menentukan berapa laba yang harus dibayarkan (dividen) kepada pemegang saham dan berapa banyak yang harus ditanam kembali (laba ditahan).

\section{Return On Equity (ROE)}

Menurut Mohammed (2007) dalam Adil et al. (2011) return on equity adalah jumlah laba bersih kembali sebagai presentase dari ekuitas pemegang saham. Return on equity digunakan untuk mengukur profitabilitas perusahaan dengan mengungkapkan 
berapa banyak keuntungan yang dihasilkan perusahaan dengan uang yang pemegang saham telah investasikan.

\subsection{Earnings per Share (EPS)}

Menurut Darminto (2007) earnings per share mendeskripsikan jumlah keuntungan yang seharusnya diterima oleh para pemegang saham sesuai dengan jumlah lembar saham yang dimiliki. Earning per share tidak selalu dibagikan, maka apabila perusahaan memerlukannya maka tidak dibagikan kepada para pemegang saham.

\section{Operating Cash Flow (OCF)}

Menurut Mohammed (2007) dalam Adil et al. (2011) operating cash flow menandakan kemampuan perusahaan untuk membayar utang, membayar dividen, membeli kembali saham dan memfasilitasi pertumbuhan bisnis yaitu ukuran fleksibilitas perusahaan. Arus kas mewakili liquiditas dan memang data arus kas penting untuk menilai liquiditas dan solvabilitas perusahaan. Arus kas untuk masa depan, tentu saja adalah sebuah potensi masukan yang penting untuk model penilaian saham dan keprihatinan untuk para kreditur perusahaan.

\section{Ukuran Perusahaan (Size)}

Menurut Farinha (2002) dalam Chasanah (2008) ukuran perusahaaan (size) adalah ukuran besar kecilnya suatu perusahaan. Perusahaan yang lebih besar dengan akses pasar yang lebih baik seharusnya membayar dividen yang lebih tinggi kepada pemegang sahamnya, sehingga antara ukuran dan pembayaran dividen memiliki hubungan yang positif.

\section{Debt to Equity Ratio (DER)}

Rasio ini mencerminkan kemampuan perusahaan dalam memenuhi seluruh kewajibannya yang ditunjukkan oleh beberapa bagian modal sendiri yang digunakan untuk membayar hutang (Deitiana 2009). Peningkatan hutang ini akan mempengaruhi tingkat pendapatan bersih yang tersedia bagi pemegang saham, artinya semakin tinggi kewajiban perusahaan, akan semakin menurunkan kemampuan perusahaan dalam membayar dividen (Deitiana 2009).

\section{Current Ratio (CR)}

Menurut Sartono (2001) dalam Latiefasari (2011) rasio ini menunjukkan sejauh mana kewajiban lancar (current liabilities) dijamin pembayarannya oleh aset lancar (current asset) (Deitiana 2009). Current ratio digunakan untuk mengukur seberapa besar kemampuan perusahaan dalam memenuhi kewajiban jangka pendeknya terhadap aktiva lancar yang dimiliki perusahaan tersebut (Kurniawan 2013).

\section{Pertumbuhan Perusahaan (Growth)}

Pertumbuhan perusahaan (Growth) menunjukkan pertumbuhan aset dimana aset merupakan aktiva yang digunakan untuk aktivitas operasional perusahaan (Latiefasari 2011). Perusahaan yang semakin cepat tingkat pertumbuhannya, akan membutuhkan dana yang semakin besar pula untuk membiayai pertumbuhannya di masa mendatang. 
Penelitian Terdahulu

\section{Return on equity dengan dividend payout ratio}

Hasil penelitian yang dilakukan oleh Adil et al. (2011) menunjukkan bahwa ada hubungan yang kuat antara ROE (return on equity) dengan DPR (dividend payout ratio). Sedangkan penelitian yang dilakukan oleh Latiefasari (2011) menunjukkan return on equity positif dan tidak berpengaruh signifikan terhadap dividend payout ratio. Berbeda dengan hasil penelitian yang dilakukan oleh Deitiana (2013) yang menunjukkan bahwa tidak ada pengaruh antara return on equity terhadap dividend payout ratio.

\section{Earnings per share dengan dividend payout ratio}

Hasil penelitian yang dilakukan oleh Adil et al. (2011) menunjukkan bahwa ada hubungan yang kuat antara EPS (Earnings per Share) dengan DPR (dividend payout ratio). Demikian pula dengan penelitian yang dilakukan oleh Darminto (2007) dan Sumiadji (2011) yang menunjukkan bahwa terdapat pengaruh antara earnings per share terhadap dividend payout ratio. Jika perusahaan memiliki tingkat keuntungan bersih yang tinggi maka kemampuan perusahaan dalam membayarkan dividen juga tinggi.

\section{Operating cash flow dengan dividend payout ratio}

Hasil penelitian yang dilakukan oleh Adil et al. (2011) menunjukkan bahwa operating cash flow memiliki hubungan yang positif dan kuat terhadap dividend payout ratio. Berbeda dengan hasil penelitian yang dilakukan oleh Rehman dan Takumi (2012) yang menunjukkan bahwa operating cash flow mempunyai hubungan negatif dengan dividend payout ratio. arus kas dipertimbangkan sebagai ukuran yang relevan untuk income perusahaan yang digunakan, salah satunya adalah untuk pembayaran dividen kas.

\section{Size dengan dividend payout ratio}

Hasil penelitian Adil et al. (2011) menunjukkan bahwa size (S) memiliki hubungan yang positif dan lemah terhadap dividend payout ratio. Sedangkan hasil penelitian yang dilakukan oleh Rafique (2012) yang menunjukkan bahwa size memiliki pengaruh positif terhadap dividend payout ratio. Pada perusahaan besar dengan total aktiva yang besar perusahaan akan lebih berani untuk menggunakan modal dari pinjaman dalam mendanai seluruh aktivanya baik aktiva tetap maupun aktiva lancar yang digunakan dalam kegiatan operasi.

\section{Debt to equity ratio dengan dividend payout ratio}

Hasil penelitian yang dilakukan oleh Deitiana (2009) menunjukkan bahwa debt to equity ratio (DER) tidak ada pengaruh yang signifikan terhadap dividend payout ratio (DPR). Sedangkan hasil penelitian yang dilakukan oleh Marietta dan Sampurno (2013) menunjukkan bahwa DER berpengaruh positif dan signifikan terhadap dividend payout ratio. Semakin besarnya hutang perusahaan berarti bunga dan angsuran yang harus dibayar juga semakin besar, maka jumlah laba yang dapat digunakan membayar dividen kepada para pemegang saham biasa akan semakin kecil.

\section{Current ratio dengan dividend payout ratio}

Hasil penelitian yang dilakukan oleh Deitiana (2013) menunjukkan bahwa tidak ada pengaruh current ratio terhadap dividend payout ratio. Demikian pula dengan hasil 
penelitian yang dilakukan oleh Rehman dan Takumi (2012) yang menunjukkan bahwa current ratio memiliki pengaruh positif dan tidak signifikan terhadap dividend payout ratio.

\section{Growth dengan dividend payout ratio}

Hasil penelitian yang dilakukan oleh Marietta dan Sampurno (2013) yang menunjukkan bahwa growth berpengaruh negatif dan tidak signifikan terhadap dividend payout ratio. Sedangkan menurut hasil penelitian Swastyastu et al. (2014) menunjukkan bahwa growth tidak berpengaruh terhadap dividend payout ratio.

\section{Model Penelitian}

Adapun model penelitian ini adalah sebagai berikut :

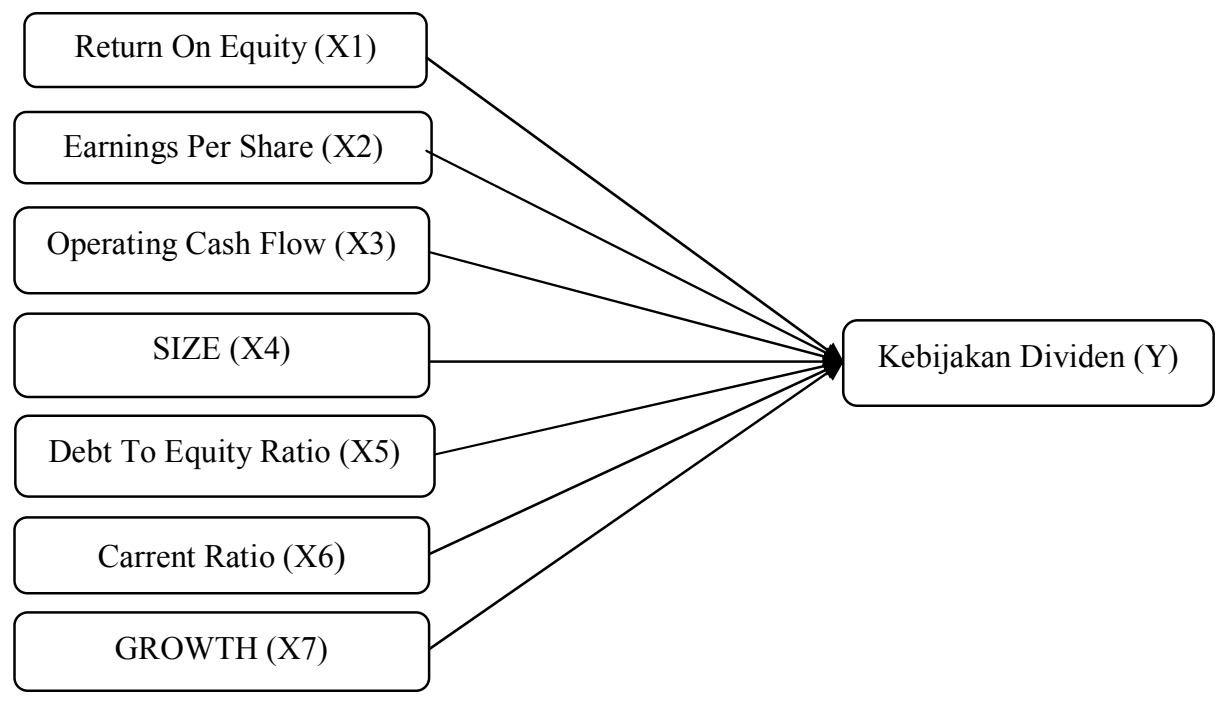

\section{Gambar \\ Faktor - faktor yang mempengaruhi kebijakan dividen}

\section{Pengembangan Hipotesis}

Adapun hipotesis dari penelitian ini adalah sebagai berikut:

$H_{1}$ : Terdapat pengaruh positif Return on equity terhadap kebijakan dividen $\mathrm{H}_{2}$ : Terdapat pengaruh positif Earnings per share terhadap kebijakan dividen $\mathrm{H}_{3}$ : Terdapat pengaruh positif Operating cash flow terhadap kebijakan dividen $H_{4}$ : Terdapat pengaruh positif Size terhadap kebijakan dividen

$H_{5}$ : Terdapat pengaruh negatif Debt to equity ratio terhadap kebijakan dividen

$H_{6}$ : Terdapat pengaruh positif Current ratio terhadap kebijakan dividen

$H_{7}$ : Terdapat pengaruh negatif Growth terhadap kebijakan dividen

\section{Metode Penelitian}

Obyek penelitian yang digunakan adalah perusahaan yang sudah melakukan Initial Public Offering (IPO) dan telah terdaftar pada Bursa Efek Indonesia (BEI). Perusahaan tersebut adalah perusahaan manufaktur yang mempublikasikan laporan keuangannya pada periode penelitian yaitu pada tahun 2014 sampai dengan tahun 2016. Populasi pada penelitian ini adalah perusahaan manufaktur yang terdaftar di Bursa Efek Indonesia ( BEI ) yang mempunyai tingkat pembayaran dividen yang cukup baik seperti pada sektor industri dasar dan kimia, aneka industri, dan industri barang 
konsumsi dalam periode 2014 - 2016. Dari jumlah total 144 perusahaan yang terdaftar di BEI dari tahun 2014 sampai dengan tahun 2016, jumlah sampel yang digunakan dalam penelitian ini adalah sebanyak 38 perusahaan. Teknik pengambilan sampel diambil dengan teknik purposive sampling yaitu pemilihan anggota sampel dengan berdasarkan pada kriteria - kriteria tertentu. Adapun kriteria-kriteria yang digunakan dalam penelitian ini mencakup :

Tabel 1

Prosedur Pemilihan Sampel

\begin{tabular}{|l|c|c|}
\hline \multicolumn{1}{|c|}{ Kriteria Sampel } & $\begin{array}{c}\text { JumlahSampel } \\
\text { per Tahun }\end{array}$ & $\begin{array}{c}\text { Total } \\
\text { Sampel }\end{array}$ \\
\hline $\begin{array}{l}\text { Perusahaan yang terdaftar di Bursa Efek Indonesia } \\
\text { sejak tahun 2014 sampai dengan 2016 }\end{array}$ & 144 & 432 \\
\hline $\begin{array}{l}\text { Perusahaan yang tidak menerbitkan laporan keuangan } \\
\text { setiap tanggal 31 Desember }\end{array}$ & $(11)$ & $(33)$ \\
\hline $\begin{array}{l}\text { Perusahaan yang tidak menerbitkan laporan keuangan } \\
\text { dalam mata uang rupiah }\end{array}$ & $(25)$ & $(75)$ \\
\hline $\begin{array}{l}\text { Perusahaan yang tidak memiliki earning after tax yang } \\
\text { positif secara berturut-turut selama periode } \\
\text { pengamatan }\end{array}$ & $(30)$ & $(120)$ \\
\hline $\begin{array}{l}\text { Perusahaan yang tidak membagikan dividen secara } \\
\text { berturut-turut selama periode pengamatan }\end{array}$ & $(40)$ & 114 \\
\hline Jumlah perusahaan dan data yang digunakan & 38 & \\
\hline
\end{tabular}

Pada bagian ini akan dijelaskan definisi operasional setiap variabel yang digunakan dalam penelitian ini termasuk alat ukurnya. Sehingga dapat diketahui definisi dan peranan sesungguhnya dari variabel - variabel tersebut. Tentunya pengukuran variabel yang disajikan menurut sumber dan referensi yang dapat dipertanggung - jawabkan. Terdapat dua jenis variabel dalam penelitian ini, yaitu variabel dependen dan variabel independen.

\section{Variabel Dependen}

\section{Kebijakan Dividen (DPR)}

Variabel dependen dalam penelitian ini adalah Dividend Payout Ratio (DPR). Pengertian kebijakan dividen yaitu jumlah dividen yang akan dibayarkan manajemen kepada pemegang saham berdasarkan keputusan yang dibuat oleh manajemen perusahaan. Sedangkan Dividend Payout Ratio (DPR) adalah prosentase laba yang dibagikan dalam bentuk dividen tunai (Adil et al. 2011), yang dapat dihitung dengan rumus sebagai berikut:

Dimana:

$$
D P R=\frac{D P S}{E P S}
$$

DPR: Dividend Payout Ratio

DPS: Dividen per lembar saham

EPS: Laba per lembar saham

\section{Variabel Independen}

\section{Return On Equity (ROE)}

Return On Equity (ROE) merupakan jumlah nilai laba bersih yang dapat dikembalikan ke pemegang saham dalam bentuk persentase. Semakin tinggi rasio ini 
berarti semakin baik kemampuan manajemen dalam menghasilkan laba dari uang yang diinvestasikan oleh investor. Skala yang digunakan adalah skala rasio. ROE juga merupakan rasio earning after tax terhadap shareholders equity (Adil et al. 2011). Formulanya adalah:

$$
R O E=\frac{\text { Net Income after } \text { Tax }}{\text { Shareholders equity }}
$$

\section{Earnings per Share (EPS)}

Pengukuran earnings per share adalah dengan cara membandingkan antara laba bersih dengan jumlah saham yang beredar di pasar (outstanding). Earnings per share (EPS) menunjukkan bagian laba perusahaan yang dialokasikan ke setiap lembar saham biasa yang beredar. Dengan kata lain EPS juga dapat diartikan sebagai persentase atau jumlah uang yang dibayarkan kepada pemegang saham (Adil et al. 2011). Skala yang digunakan adalah skala rasio. Formulanya adalah:

$$
E P S=\frac{\text { Net Income }}{\text { Average outstanding shares }}
$$

\section{Operating Cash Flow (OCF)}

Operating cash flow menunjukkan arus kas yang dihasilkan perusahaan dari selisih bersih penerimaan dan pengeluaran kas serta setara kas yang berasal dari aktivitas operasi perusahaan selama satu tahun buku. Aktivitas operasi meliputi pendapatan dan beban yang berasal dari transaksi perusahaan. Operating cash flow merupakan penentu dividen yang lebih penting dari pada profitabilitas sebagaimana arus kas menentukan kemampuan perusahaan untuk membayar dividen (Irawan dan Nurdhiana 2011). Formulanya adalah:

$\mathrm{OCF}=$ Kas masuk dari kegiatan operasi - kas keluar dari kegiatan operasi

\section{Ukuran Perusahaan (Size)}

Size menggambarkan besar kecilnya total aktiva yang dimiliki oleh suatu perusahaan. Ukuran perusahaan juga memainkan peran dalam menjelaskan kebijakan dividen perusahaan. Pengukuran ukuran perusahaan (size) dilakukan dengan menggunakan logaritma natural dari total aset perusahaan (Adil et al. 2011).

Size $=$ Ln TA

Keterangan:

Ln TA = Logaritma natural Total Asset

\section{Debt to Equity Ratio (DER)}

Debt to equity ratio merupakan rasio yang digunakan untuk mengukur tingkat leverage (penggunaan utang) terhadap total shareholder equity yang dimiliki perusahaan. Rasio ini juga dapat disebut sebagai perbandingan dana pihak luar dengan dana pemilik perusahaan yang dimasukkan ke dalam perusahaan. Debt to equity ratio mencerminkan kemampuan perusahaan dalam memenuhi seluruh kewajibannya, yang ditunjukkan dengan beberapa bagian modal yang dimiliki perusahaan yang dipakai untuk membayar hutang (Deitiana 2009). Formulanya adalah:

$$
\text { Debt to Equity Ratio }=\frac{\text { Total Liabilities }}{\text { Total Equity }}
$$

\section{Current Ratio (CR)}

Rasio lancar atau current ratio adalah rasio yang membandingkan aktiva lancar yang dimiliki perusahaan dengan utang jangka pendek. Likuiditas merupakan 
pertimbangan utama dalam kebijakan pembayaran dividen. Untuk itu current ratio digunakan untuk mengukur seberapa besar kemampuan perusahaan dalam memenuhi kewajiban jangka pendeknya terhadap aktiva lancar yang mereka miliki (Deitiana 2013). Formulanya adalah:

$$
\text { Current Ratio }=\frac{\text { Current Assets }}{\text { Current Liabilities }}
$$

\section{Pertumbuhan Perusahaan (Growth)}

Pertumbuhan pada total asset yang besar akan menurunkan pembayaran deviden kepada pemegang saham, karena semakin tinggi tingkat pertumbuhan suatu perusahaan akan semakin besar tingkat kebutuhan dana untuk membiayai ekspansi. Pertumbuhan perusahaan (growth) dirumuskan dengan cara membandingkan total aset tahun sekarang dikurangi total aset tahun lalu dengan total aset tahun lalu (Marietta \& Sampurno 2013).

$$
\text { Growth }=\frac{\text { Total } \text { Assets }_{t}-\text { Total Assets }_{t-1}}{\text { Total Assets }_{t-1}}
$$

Teknik analisis data yang digunakan didalam penelitian ini dilakukan dengan menggunakan analisis regresi berganda. Analisis regresi berganda adalah teknik statistik melalui koefisien parameter untuk mengetahui besarnya pengaruh variabel independen terhadap variabel dependen. Persamaan regresi linier berganda yang digunakan dalam penelitian adalah sebagai berikut :$$
\mathrm{DPR}=\alpha+\beta 1 \mathrm{ROE}+\beta 2 \mathrm{EPS}+\beta 30 \mathrm{CF}+\beta 4 \mathrm{SIZE}+\beta \text { 5DER + } \beta 6 \mathrm{CR}+
$$$$
\beta 7 G R O W T H+e
$$

Keterangan:

$\begin{array}{ll}\text { DPR } & =\text { Dividend Payout Ratio } \\ \alpha & =\text { konstanta } \\ \beta 1 & =\text { koefisien variabel independen Return on Equity } \\ \beta 2 & =\text { koefisien variabel independen Earnings per Share } \\ \beta 3 & =\text { koefisien variabel independen Operating Cash Flow } \\ \beta 4 & =\text { koefsien variabel independen Size } \\ \beta 5 & =\text { koefisien variabel independen Debt to Equity Ratio } \\ \beta 6 & =\text { koefisien variabel independen Current Ratio } \\ \beta 7 & =\text { koefisien variabel independen Growth } \\ \text { ROE } & =\text { Return on Equity } \\ \text { EPS } & =\text { Earnings per Share } \\ \text { OCF } & =\text { Operating Cash Flow } \\ \text { SIZE } & =\text { Ukuran Perusahaan } \\ \text { DER } & =\text { Debt to Equity Ratio } \\ \text { CR } & =\text { Current Ratio } \\ \text { GROWTH } & =\text { Pertumbuhan Perusahaan } \\ \text { e } & =\text { Standard Error }\end{array}$

\section{Uji Signifikansi Parameter Individual (Uji Statistik t)}

Uji statistik t pada dasarnya menunjukkan seberapa jauh pengaruh satu variabel independen secara individual dalam menerangkan variasi variabel dependen (Ghozali 2013). Menurut Santoso (2012) jika tingkat signifikansi lebih besar atau sama dengan dari 0,05 maka Ha ditolak, dan sebaliknya apabila tingkat signifikansinya lebih kecil 
dari 0,05 maka Ha diterima. Jika Ha ditolak berarti dengan tingkat kepercayaan tertentu (5\%) variabel independen yang diuji secara nyata berpengaruh terhadap variabel dependen dan sebaliknya jika Ha diterima berarti variabel independen yang diuji secara nyata tidak berpengaruh terhadap variabel dependen.

\section{Hasil dan Pembahasan}

\section{Deskripsi Statistik Kualitatif}

Statistik deskriptif menunjukkan nilai rata - rata (mean), maksimum, minimum dan deviasi standar untuk masing - masing variabel penelitian pada tahun 2014 sampai tahun 2016. Untuk mengetahui karakteristik sampel yang digunakan, dapat dilihat pada tabel berikut ini:

\section{Tabel 2}

\section{Hasil Pengolahan Statistik Deskriptif}

\begin{tabular}{|l|l|l|l|l|l|}
\hline & $\mathrm{N}$ & Minimum & Maximum & Mean & Std. Deviation \\
\hline DPR & 114 & 0,03 & 1,25 & 0,4418 & 0,26304 \\
ROE & 114 & 0,02 & 1,26 & 0,2489 & 0,20578 \\
EPS & 114 & 8,65 & $16.515,00$ & $1.486,9227$ & $3.192,93514$ \\
OCF & 114 & -713.749 & $21.250,000$ & 1.510 .685 & $3.044,272$ \\
SIZE & 114 & 25,31 & 33,00 & 28,7705 & 1,72624 \\
DER & 114 & 0,11 & 3,19 & 0,7782 & 0,60707 \\
CR & 114 & 0,64 & 11,74 & 2,8440 & 1,93715 \\
GROWTH & 114 & $-0,12$ & 0,59 & 0,1878 & 0,13252 \\
\hline
\end{tabular}

Sumber: Pengolahan data SPSS 19

Tabel di atas menunjukkan hasil uji statistik setelah yaitu sebagai berikut:

Berdasarkan hasil pengolahan data pada diatas diketahui bahwa Variabel Dividend Payout Ratio (DPR) diperoleh rata-rata sebesar 0,4418. Hal ini berarti bahwa rata-rata kebijakan pembagian dividen tunai adalah sebesar $0,4418 \%$ dari laba per lembar saham yang diperoleh perusahaan. Nilai maximum sebesar $1,25 \%$ yang berarti bahwa deviden tertinggi dari perusahaan sampel dapat mencapai 1,2\% dari laba per lembar saham yang diperoleh perusahaan, sedangkan nilai minimum DPR adalah $0,22 \%$ dari laba per lembar saham yang diperoleh.

Variabel Return On Equity (ROE) menunjukkan rata-rata sebesar 0,2489. Hal ini berarti rata-rata perusahaan mampu mendapatkan laba bersih sebesar $0,2489 \%$ dari total asset yang dimiliki perusahaan dalam satu periode. Nilai maximumnya sebesar 1,26\% dari total asset dan nilai minimumnya sebesar 0,02\% dari total asset.

Variabel Earning Per Share (EPS) menunjukkan nilai rata-rata sebesar 1.486,9227\%. Hal ini berarti bahwa rata-rata perusahaan sampel mampu mendapatkan laba bersih sebesar $1.486,9227 \%$ dari total asset yang dimiliki perusahaan dalam satu periode. Nilai minimum yaitu sebesar $8,65 \%$ yang berarti sampel terendah hanya mendapatkan laba bersih dari seluruh total asset yang dimiliki sebesar $8,65 \%$ dan nilai maximum diketahui sebesar $16.515,00 \%$.

Variabel Operating Cash Flow (OCF) menunjukkan nilai rata-rata sebesar $1.510,685 \%$. Hal ini berarti bahwa rata-rata perusahaan sampel mampu mendapatkan laba bersih sebesar $1.510,685 \%$ dari total asset yang dimiliki perusahaan dalam satu periode. Nilai minimum yaitu sebesar $-713.749 \%$ yang berarti sampel terendah hanya mendapatkan laba bersih dari seluruh total asset yang dimiliki sebesar $-713.749 \%$ dan nilai maximum diketahui sebesar $21,250 \%$.

Variabel Size yang merupakan Log natural dari Total Asset menunjukkan rata-rata sebesar 28,7705. Sedangkan nilai maximumnya adalah 33,00 dan nilai minimumnya 25,31 . 
Variabel Debt to Equity Ratio (DER) yang merupakan rasio total hutang dengan total ekuitas perusahaan menunjukkan nilai rata-rata sebesar 0,7782. Hal ini berarti bahwa rata-rata perusahaan sampel memiliki hutang sebesar 0,7782 kali lebih besar dari modal sendiri (ekuitas) yang dimiliki perusahaan. Nilai minimum dari DER adalah sebesar 0,11 yang berarti bahwa sampel terendah hanya memiliki hutang sebesar 0,11 kali dari modal sendiri, sedangkan nilai maximum DER sebesar 3,19 atau dimilikinya hutang sebesar 319 kali modal sendiri yang dimiliki perusahaan.

Variabel Current Ratio (CR) menunjukkan rata-rata sebesar 2,8440. Hal ini berarti rata-rata perusahaan sampel mampu memenuhi kewajiban jangka pendeknya sebesar 2,8440 kali dari total asset yang dimiliki perusahaan dalam satu periode. Nilai maximumnya sebesar 11,74 kali dari total asset dan nilai minimumnya sebesar 0,64 kali dari total asset.

Pertumbuhan perusahaan (Growth) memiliki nilai terendah sebesar -0,12 dan nilai tertinggi sebesar 0,59. Rata-rata variabel ukuran perusahaan sebesar 0,1878, standar deviasi menunjukkan angka 0,13252. Nilai rata-rata (mean) lebih besar dari standar deviasi yaitu 0,1878 > 0,13252, berarti bahwa sebaran nilai Debt to Equity Ratio baik. Data tersebut bersifat homogen dimana tingkat kesenjangan relative kecil antara variabel growth terendah dan tertinggi selama periode penelitian.

\section{Hasil Analisis Regresi}

Analisis regresi linier digunakan dalam penelitian ini dengan tujuan untuk mengetahui ada tidaknya pengaruh variabel bebas (Ghozali,2001). Adapun hasil pengolahan data sebagi berikut :

Tabel 3

Hasil Analisis Regresi

\begin{tabular}{|c|c|c|c|c|c|}
\hline \multirow[b]{2}{*}{ Model } & \multicolumn{2}{|c|}{ Unstandardized Coefficients } & \multirow{2}{*}{$\begin{array}{c}\begin{array}{c}\text { Standardized } \\
\text { Coefficients }\end{array} \\
\text { Beta }\end{array}$} & \multirow[b]{2}{*}{$\mathbf{t}$} & \multirow[b]{2}{*}{ Sig. } \\
\hline & B & Std. Error & & & \\
\hline (Constant) & ,060 & ,499 & & ,120 & ,904 \\
\hline Return on Equity & ,323 & 115 & ,253 & 2,801 & 006 \\
\hline Earnings Per Share & 3,209 & 000 & 390 & 4,269 & 000 \\
\hline Operating Cash Flow & 6,183 & ,000 & ,072 & ,616 &, 539 \\
\hline Size & ,014 & ,018 & ,091 & ,791 & ,431 \\
\hline Debt to Equity Ratio &,- 062 & ,043 & -144 & $-1,441$ & 152 \\
\hline Current Ratio &,- 013 & -014 & 098 &,- 980 & ,329 \\
\hline Growth & -366 & 169 & -184 & $-2,168$ & 032 \\
\hline
\end{tabular}

Berdasarkan hasil pengujian dengan metode regresi linier berganda untuk menguji pengaruh variabel-variabel independen (ROE, EPS, OCF, SIZE, DER, CR, GROWTH) terhadap variabel dependen (DPR) maka dapat disusun sebuah persamaan sebagai berikut :

\section{DPR = 0,060 + 0,323 ROE + 0,3209 EPS + 6,183 OCF + 0,014 SIZE - 0,062 DER - 0,013 CR - 0,366 GROWTH + e}

Hasil tersebut dapat dijelaskan sebagai berikut :

Koefisien regresi Return on Equity (ROE) adalah sebesar 0,253 yang berarti bahwa setiap peningkatan ROE sebesar 1\% akan meningkatkan DPR sebesar 25.3\% dengan asumsi variabel lain konstan. Koefisien regresi Earnings Per Share (EPS) adalah sebesar 0,390 yang berarti bahwa setiap peningkatan EPS sebesar Rp 1 akan meningkatkan DPR sebesar 39,0\% dengan asumsi variabel lain konstan. Koefisien regresi Operating Cash 
Flow (OCF) adalah sebesar 0,072 yang berarti bahwa setiap peningkatan OCF sebesar $1 \%$ akan meningkatkan DPR sebesar $07.2 \%$ dengan asumsi variabel lain konstan. Koefisien regresi ukuran perusahaan (SIZE) adalah sebesar 0,091yang berarti bahwa setiap peningkatan ukuran perusahaan sebesar satu satuan akan meningkatkan DPR sebesar 09,1\% dengan asumsi variabel lain konstan. Koefisien regresi Debt to Equity Ratio (DER) adalah sebesar -0,144 yang berarti bahwa setiap peningkatan DER sebesar satu satuan akan menurunkan DPR sebesar 14,4\% dengan asumsi variabel lain konstan. Koefisien regresi Current Ratio (CR) adalah sebesar 0,098 yang berarti bahwa setiap peningkatan CR sebesar 1\% akan meningkatkan DPR sebesar 09,8\% dengan asumsi variabel lain konstan. Koefisien regresi Pertumbuhan Perusahaan (GROWTH) adalah sebesar -0,184 yang berarti bahwa setiap peningkatan GROWTH sebesar 1\% akan menurunkan DPR sebesar 18,4\% dengan asumsi variabel lain konstan.

Tabel 4

Hasil Uji t

\begin{tabular}{|c|c|c|c|c|c|}
\hline \multirow[b]{2}{*}{ Model } & \multicolumn{2}{|c|}{ Unstandardized Coefficients } & \multirow{2}{*}{$\begin{array}{c}\begin{array}{c}\text { Standardized } \\
\text { Coefficients }\end{array} \\
\text { Beta } \\
\end{array}$} & \multirow[b]{2}{*}{$\mathbf{t}$} & \multirow[b]{2}{*}{ Sig. } \\
\hline & B & Std. Error & & & \\
\hline 1 (Constant) & ,060 & ,499 & & ,120 & ,904 \\
\hline Return on Equity & 323 & 115 & ,253 & 2,801 & ,006 \\
\hline Earnings Per Share & 3,209 & 000 & 390 & 4,269 & ,000 \\
\hline Operating Cash Flow & 6,183 & ,000 & ,072 & ,616 & ,539 \\
\hline Size & ,014 & ,018 & ,091 & ,791 & ,431 \\
\hline Debt to Equity Ratio &,- 062 &, 043 &,- 144 & $-1,441$ & ,152 \\
\hline Current Ratio &,- 013 & -014 & 098 &,- 980 & 329 \\
\hline Growth &,- 366 & 169 &,- 184 & $-2,168$ & ,032 \\
\hline
\end{tabular}

Berdasarkan hasil uji t pada tabel dapat disimpulkan bahwa, Nilai signifikansi return on equity (ROE) adalah sebesar 0,006 lebih kecil dari 0,05 yang berarti bahwa terdapat pengaruh positif dan signifikan return on equity terhadap kebijakan dividen (DPR). Return on equity berpengaruh positif dan signifikan terhadap kebijakan dividen karena dengan memiliki return yang besar kemungkinan dividen yang dibagikan oleh perusahaan kepada pemegang saham akan besar pula. Jika disimpulkan secara sederhana, semakin tinggi penghasilan suatu perusahaan akan semakin besar besaran dividen yang dibagikan kepada pemegang saham.

Nilai signifikansi earnings per share (EPS) adalah sebesar 0,000 lebih kecil dari 0,05 yang berarti bahwa terdapat pengaruh positif earnings per share terhadap kebijakan dividen (DPR). Earnings per share menunjukkan besarnya earnings (pendapatan) yang diperoleh dari setiap lembar saham. Semakin besar nilai EPS berarti semakin besar pendapatan yang diterima oleh pemegang saham.

Nilai signifikansi operating cash flow (OCF) adalah sebesar 0,539 lebih besar dari 0,05 yang berarti bahwa tidak terdapat pengaruh positif dan signifikan operating cash flow terhadap kebijakan dividen (DPR). Operating cash flow tidak berpengaruh positif dan signifikan terhadap kebijakan dividen karena kas yang tersedia dari kegiatan operasional perusahaan tidak hanya digunakan untuk membayar dividen saja tetapi digunakan juga untuk melunasi pinjaman jangka pendek, memelihara kemampuan operasi perusahaan, dan melakukan investasi baru tanpa mengandalkan sumber pendanaan dari luar.

Nilai signifikansi size (SIZE) adalah sebesar 0,431 lebih besar dari 0,05 yang berarti bahwa tidak terdapat pengaruh positif dan signifikan size (SIZE) terhadap 
kebijakan dividen (DPR). Size tidak berpengaruh positif dan signifikan terhadap kebijakan dividen karena Investor yang berinvestasi di saham perusahaan besar cenderung menginginkan laba yang stabil, tetapi perusahaan besar berpotensi untuk menghasilkan keuntungan yang lebih besar seperti dengan melakukan ekspansi akan tetapi modal yang digunakan juga besar, sehingga profitabilitasnya belum tentu lebih tinggi dari perusahaan kecil.

Nilai signifikansi debt to equity ratio (DER) adalah sebesar 0,152 lebih besar dari 0,05 yang berarti bahwa tidak terdapat pengaruh negatif dan signifikan debt to equity ratio (DER) terhadap kebijakan dividen (DPR). Debt to equity ratio tidak berpengaruh negatif dan signifikan terhadap kebijakan dividen karena semakin meningkatnya debt to equity ratio, maka akan berdampak pada profitabilitas perusahaan, karena sebagian dipergunakan untuk membayar pinjaman, dengan biaya bunga yang semakin besar, maka profitabilitasnya (earnings after tax) akan semakin berkurang.

Nilai signifikansi current ratio (CR) adalah sebesar 0,329 lebih besar dari 0,05 yang berarti bahwa tidak terdapat pengaruh positif dan signifikan current ratio (CR) terhadap kebijakan dividen (DPR). Current ratio tidak berpengaruh positif dan signifikan terhadap kebijakan dividen karena aset lancar perusahaan lebih dipergunakan untuk membiayai operasional jangka pendek perusahaan, membeli aset atau menginvestasikan ke proyek baru.

Nilai signifikansi growth (GROWTH) adalah sebesar 0,032 lebih kecil dari 0,05 yang berarti bahwa terdapat pengaruh negatif dan signifikan growth terhadap kebijakan dividen (DPR). Growth (GROWTH) memiliki pengaruh negatif dan signifikan terhadap kebijakan dividen karena perusahaan menggunakan laba untuk melakukan perluasan usaha (ekspansi) untuk meningkatkan produktifitas dan memperluas pangsa pasar perusahaan, jadi tidak hanya digunakan untuk membayar dividen.

\section{Kesimpulan}

Berdasarkan hasil penelitian yang dianalisis pada bab IV maka diperoleh kesimpulan sebagai berikut:

1. Return on equity berpengaruh positif dan signifikan terhadap kebijakan dividen (DPR) dengan nilai signifikansi return on equity (ROE) adalah sebesar 0,006 lebih kecil dari 0,05.

2. Earning Per Share (EPS) berpengaruh positif dan signifikan earnings per share terhadap kebijakan dividen (DPR) dengan nilai signifikan EPS adalah sebesar 0,000 lebih kecil dari 0,05.

3. Operating cash flow (OCF) tidak berpengaruh terhadap kebijakan dividen (DPR) dengan nilai signifikansi OCF adalah sebesar 0,539 lebih besar dari 0,05.

4. Ukuran perusahaan (SIZE) tidak berpengaruh yang signifikan terhadap kebijakan deviden (DPR) dengan nilai signifikansi 0,431 lebih besar dari 0,05. Hal ini berati bahwa semakin tinggi SIZE maka akan meningkatkan Divedend Payout Ratio (DPR).

5. Rasio Debt to Equity Ratio (DER) tidak berpengaruh yang signifikan terhadap kebijakan dividen (DPR) dengan nilai signifikansi sebesar 0,152 lebih besar dari 0,05. Hal ini berati bahwa semakin tinggi DER maka akan menurunkan Divedend Payout Ratio (DPR).

6. Rasio Current Ratio (CR) tidak berpengaruh yang signifikan terhadap kebijakan deviden (DPR) dengan nilai signifikan 0,329 lebih besar dari 0,05.

7. Pertumbuhan Perusahaan (GROWTH) berpengaruh negatif dan signifikan terhadap kebijakan dividen (DPR) dengan nilai signifikansi sebesar 0,032 lebih kecil dari 0,05. 
Saran

Untuk mengatasi keterbatasan dalam penelitian ini, peneliti memberikan rekomendasi penelitian sebagai berikut:

1. Penelitian selanjutnya dapat memperpanjang periode penelitian selanjutnya menjadi 5 tahun, sehingga diharapkan dapat mencerminkan kondisi perusahaan dengan lebih jelas dan hasil pengujian dapat lebih akurat.

2. Penelitian selanjutnya dapat menambah variabel independen lainnya yang belum dimasukkan dalam penelitian ini, seperti kepemilikan institusional, cash ratio, net profit margin dan lain-lain.

3. Penelitian selanjutnya dapat memperluas objek penelitian dan tidak terbatas pada sektor manufaktur saja, sehingga dapat lebih mencerminkan kebijakan dividen pada perusahaan yang terdaftar di BEI secara keseluruhan.

\section{Ucapan Terima Kasih}

Terima Kasih tim peneliti ucapkan kepada Yayasan Pendidikan Nasional Tridinanti (YPNT) Universitas Tridinanti Palembang yang telah memberikan dukungan moril dan bantuan Dana Penelitian Tahun Anggaran 2018/2019 Nomor: 078/UTP.A12/LPPM/IV/2018 kepada tim peneliti.

\section{Referensi}

Adil, C. M., Nousheen Zafar, dan Noman Yaseen. 2011. Empirical Analysis of Determinants of Dividend Payout: Profitability and Liquidity. Interdisciplinary Journal of Contemporary Research Business, May, Vol. 3, No. 1, hlm. 289-300.

Chasanah,AmaliaNur,2008. "Faktor-FaktorYang Mempengaruhi Dividen Payout Ratio (DPR) Pada Perusahaan Yang Listed Di Bursa Efek Indonesia”.Tesis.Universitas Diponegoro, Semarang.

Deitiana, Tita. 2009. Faktor-Faktor yang Mempengaruhi Kebijakan Pembayaran Dividen Kas. Jurnal Bisnis dan Akuntansi, April, Vol. 11, No. 1, hlm.57-64.

Deitiana, Tita. 2013. Pengaruh Current Ratio, Return on Equity dan Total Asset Turn over terhadap Dividend Payout Ratio dan Implikasi pada Harga Saham Perusahaan LQ 45. Jurnal Bisnis dan Akuntansi, Juni, Vol. 15, No. 1, hlm. 82-88.

Darminto. 2007. Factors Influencing Dividend Policy. Jurnal Administrasi Bisnis, Desember, Vol.1, No.2, hlm.110-122.

Embara, Cecilia Triana D. Lestari, Ni Luh P. Wiagustini, dan Ida Bagus Badjra. 2012. Variabel-Variabel yang Berpengaruh terhadap Kebijakan Dividen serta Harga saham pada perusahaan Manufaktur di Bursa Efek Indonesia. Jurnal Manajemen, Strategi Bisnis, dan Kewirausahaan, Vol.1, No. 2.

Ghozali, Imam. 2012. Aplikasi Analisis Multivariate dengan Program IBM SPSS 20. Badan Penerbit Universitas Diponegoro: Semarang.

Ghozali, Imam. 2013. Aplikasi Analisis Multivariate dengan Program IBM SPSS 21. Badan Penerbit Universitas Diponegoro: Semarang. 
Kurniawan, Iwan. 2013. Variabel-Variabel yang Mempengaruhi Kebijakan Pembayaran Dividen pada Perusahaan Industri Otomotif yang Terdaftar di Bursa Efek Indonesia. Jurnal ilmiah Mahasiswa, Februari.

Latiefasari, Hani D. 2011. Analisis Faktor-Faktor yang Mempengaruhi Kebijakan Dividend (Study Empiris pada Perusahaan Manufaktur yang Terdaftar di BEI periode 2005-2009). Skripsi Program Sarjana Universitas Diponegoro

Marietta, Unzu dan Djoko Sampurno. 2013. Analisis Pengaruh Cash Ratio, Return On Assets, Growth, Firm Size, Debt to Equity Ratio terhadap Dividend Payout Ratio: (Study Pada Perusahaan Manufaktur yang Terdaftar di Bursa Efek Indonesia Tahun 2008-2011). Diponegoro Journal of Management 1, Vol. 2, No. 3.

Rafique, Mahira. 2012. "Factors Affecting Dividend Payout: Evidence From Listed NonFinancial Firms of Karachi Stock Exchange", Business Management Dynamics, Vol.1, No.11, pp. 76-92.

Rehman, Abdul dan Haruto Takumi. 2012. Determinants of Dividend Payout Ratio: Evidence from Karachi Stock Exchange (KSE). Journal of Contemporary Issues in Business Research, Vol. 1, No. 1, pp. 20-27.

Santoso, Singgih. 2012. Buku Latihan SPSS Statistik Parametrik. PT. Elex Media Komputindo: Jakarta.

Sumiadji. 2011. Analisis variabel keuangan yang mempengaruhi Kebijakan deviden. Jurnal Dinamika Akuntansi, September, Vol. 3, No. 2.

Suwaldiman dan Ahmad Aziz. 2006. Pengaruh Insider Ownership dan Resiko Pasar Terhadap Kebijakan Dividen. Sinergi Kajian Bisnis dan Manajemen, Januari, Vol. 8, No. 1, hlm. 53-64. 